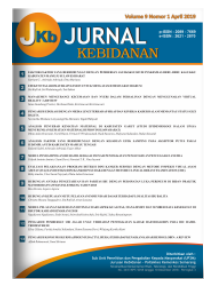

Volume 9 Nomor 2 (2019) 125-129

JURNAL KEBIDANAN

p-ISSN: 2089-7669 ; e-ISSN: 2621-2870

http://dx.doi.org/10.31983/jkb.v9i2.4498

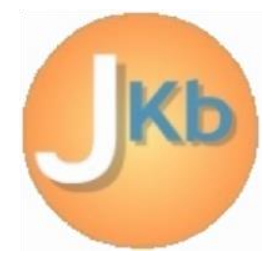

\title{
Pregnant Women's Perception about HIV / AIDS with the Implementation of HIV Tests
}

\author{
NNA Widiani ${ }^{1}$ JDM Sriwitati ${ }^{2}$ \\ 1,2 Politeknik Kesehatan Kartini Bali \\ Corresponding author: NNA Widiani ${ }^{1}$ \\ Email: ayukwidiani@yahoo.co.id
}

Received: Juny 12th, 2019; Revised: September $3^{\text {th }}, 2019$; Accepted: September $17^{\text {th }}, 2019$

\begin{abstract}
One of the infectious diseases that is being talked about is HIV / AIDS, an infectious disease caused by infection with the Human Immunodeficiency Virus. The number of new cases of HIV / AIDS in Indonesia tends to fluctuate. The purpose of this study was to determine the relationship between perceptions of pregnant women about HIV / AIDS with the implementation of the HIV test. The design of this study was questionnaire based survey with cross sectional approach, to determine the factors that influence the implementation of HIV test in pregnant women. The population in this study were all pregnant women in the working area of Puskesmas II Denpasar Barat, amounting to 573 people and a sample of 82 people. The sampling technique used was consecutive sampling. Chi Square statistical test and Logistic Regression were applied for bivariate and multivariate analysis respectively. The results showed that there was a relationship between the perception of vulnerability of pregnant women about HIV / AIDS and the implementation of the HIV test $(\mathrm{p}=0.002)$, there was a relationship between the perception of the severity of pregnant women and the HIV test $(p=0.019)$, HIV test $(p=0.006)$, there was a relationship between the perception of obstacle for pregnant women and the implementation of the HIV test $(p=0.009)$, the most dominant variable associated with the implementation of the HIV test was perception of vulnerability ( $\mathrm{p}=0.004$, OR: $5.885,95 \%$ CI $1,776-19,493)$. There is significant relationship between perception with HIV testing and vulnerability perception is the most dominant variable affecting HIV testing. The results of this study it is recommended to increase health promotion related to the implementation of HIV testing and its benefits so that pregnant women are willing to carry out HIV testing.
\end{abstract}

Keyword: perception; HIV/AIDS; pregnant women; HIV test

\section{Pendahuluan}

Salah satu penyakit menular yang sedang marak dibicarakan antara lain HIV/AIDS yaitu penyakit menular yang disebabkan oleh infeksi Human Immunodeficiency Virus yang menyerang sistem kekebalan tubuh[1]. Secara nasional, jumlah kasus baru HIV/AIDS di Indonesia cenderung mengalami fluktuasi dari tahun ke tahun. Hal ini, terlihat dari jumlah peningkatan kasus baru HIV/AIDS pada tahun 2012 di Indonesia sebanyak 31.160 kasus, tahun 2013 sebanyak 39.200 kasus, sedangkan tahun 2014 sebanyak 38.205 kasus baru HIV/AIDS[2].

Dinas Kesehatan Kota Denpasar (2016) melaporkan bahwa, kasus HIV di Kota Denpasar dari tahun 2012 sampai dengan tahun 2016 meningkat secara signifikan, yaitu berturut-turut: berjumlah 294 kasus, 290 kasus, 332 kasus, 638 kasus, 626 kasus. Sementara kasus AIDS berjumlah 611 kasus, kondisi ini lebih banyak dari jumlah pada tahun 2015. Sementara kasus sesuai kelompok umur tertinggi adalah kelompok umur 20-24 tahun berjumlah 67 kasus, dan kelompok 2549 tahun berjumlah 436 kasus, dimana usia 25-49 
tahun tersebut merupakan kelompok umur produktif[3]. Penelitian Sriwitati (2014) tentang pemanfaatan pelayanan tes HIV pada ibu hamil di BPM wilayah kerja Puskesmas II Denpasar Barat menunjukkan bahwa jumlah ibu hamil yang belum melakukan tes HIV masih cukup tinggi yaitu 92,29\% dari 1287 ibu hamil, sementara saat itu layanan dalam bentuk program tes HIV atau tes PPIA sudah diterapkan. Faktor dominan yang berhubungan dengan pemanfaatan pelayanan tes $H I V$ adalah dukungan suami/keluarga, persepsi ibu hamil dan dikontrol oleh variabel sikap dan ketersediaan pelayanan[4].

Ada pengaruh variabel persepsi tentang HIV/AIDS dan variabel faktor pencetus untuk bertindak terhadap perilaku VCT. Seseorang akan memutuskan dirinya untuk melakukan tes $H I V$, didasari oleh persepsi dan keyakinan individu tersebut, artinya didasari oleh penilaian subyektif dari individu yang bersangkutan, dimana penilaian subjektif itu dinilai dari sudut pandang individu berdasarkan keyakinan dan kepercayaannya[5].

Berdasarkan latar belakang tersebut peneliti tertarik melakukan penelitian tentang hubungan persepsi ibu hamil tentang HIV/AIDS dengan pelaksanaan tes PPIA di wilayah kerja Puskesmas II Denpasar Barat tahun 2018.

\section{Metode Penelitian}

Rancangan penelitian ini adalah rancangan penelitian survey questionnaire based dengan desain cross sectional. Penelitian ini dilaksanakan di wilayah kerja Puskesmas II Denpasar Barat, Kota Denpasar Bali. Penelitian dilaksanakan bulan Agustus sampai September 2018. Jumlah populasi sebesar 573 orang ibu hamil dan sampel yang digunakan adalah sebesar 82 orang ibu hamil yang telah memenuhi kriteria inklusi dan eksklusi. Adapun instrument yang digunakan untuk mengukur persepsi berupa lembar kuesioner terstruktur yang berisi pertanyaan penelitian, kuesioner yang dipakai ini sebelumnya dilakukan pengujian terlebih dahulu pada sepuluh ibu hamil dengan tujuan kuesioner yang dipakai sesuai dengan pemahaman ibu hamil. Sebelum penelitian dilakukan, peneliti sudah mengurus ethical clearance dari Komisi Etik Fakultas Kedokteran Universitas Udayana dengan No: 1995/UN14.2.2.VII.14/LP/2018. Teknik analisa data bivariate yang digunakan adalah analisis $C h i$ Square $\left(\mathrm{X}^{2}\right)$ sedangkan teknik analisa multivariate adalah menggunakan regresi logistic.

\section{Hasil dan Pembahasan}

Hasil analisa secara deskriptif dapat dilihat pada tabel berikut:

\section{Tabel 1}

Distribusi frekuensi karakteristik responden berdasarkan umur, pendidikan dan pekerjaan di Wilayah Kerja Puskesmas II Denpasar Barat Tahun 2018.

\begin{tabular}{rlcc}
\hline No & Karakteristik & $\begin{array}{c}\text { Frekuensi } \\
(\mathbf{f})\end{array}$ & $\begin{array}{c}\text { Persentase } \\
(\boldsymbol{\%})\end{array}$ \\
\hline $\mathbf{1}$ & Umur & & \\
\cline { 2 - 4 } & $14-19$ tahun & 5 & 6 \\
\cline { 2 - 4 } & $20-35$ tahun & 63 & 77 \\
\cline { 2 - 4 } & $>35$ tahun & 14 & 17 \\
\hline \multirow{2}{2}{} & Pendidikan & & \\
\cline { 2 - 4 } & SD/SMP & 27 & 33 \\
\cline { 2 - 4 } & SMA & 20 & 24 \\
\hline \multirow{3}{*}{3} & PT & 35 & 43 \\
\cline { 2 - 4 } & Pekerjaan & & \\
\cline { 2 - 4 } & Tidak bekerja & 54 & 66 \\
\hline & Bekerja & 28 & 34 \\
\hline
\end{tabular}

Berdasarkan tabel 1 dapat diketahui 63 orang responden (77\%) berumur 20 - 35 tahun, 35 orang responden (43\%) berpendidikan tinggi (PT) dan 54 orang responden (66\%) tidak bekerja.

\section{Tabel 2}

Distribusi Frekuensi Persepsi Ibu hamil tentang HIV/AIDS dengan Pelaksanaan Tes HIV di Wilayah Kerja Puskesmas II Denpasar Barat Tahun 2018.

\begin{tabular}{lllc}
\hline No & \multicolumn{1}{c}{$\begin{array}{c}\text { Persepsi } \\
\text { 1 }\end{array}$} & $\begin{array}{c}\text { Frekuensi } \\
\text { (f) }\end{array}$ & $\begin{array}{c}\text { Persentase } \\
(\boldsymbol{\%})\end{array}$ \\
\cline { 2 - 4 } & Kerentanan & & \\
\cline { 2 - 4 } & Negatif & 44 & 54 \\
\hline $\mathbf{2}$ & Positif & 38 & 46 \\
\cline { 2 - 4 } & Keparahan & & \\
\cline { 2 - 4 } & Negatif & 46 & 56 \\
\hline $\mathbf{3}$ & Positif & 36 & 44 \\
\cline { 2 - 4 } & Manfaat & & \\
\cline { 2 - 4 } & Negatif & 43 & 52 \\
\hline $\mathbf{4}$ & Positif & 39 & 48 \\
\cline { 2 - 4 } & Halangan & & \\
\cline { 2 - 4 } & Negatif & 44 & 54 \\
\hline
\end{tabular}

Berdasarkan tabel 2 didapatkan hasil sebagian besar responden yaitu 44 orang (54\%) memiliki persepsi kerentanan negatif, sebagian besar responden yaitu 46 orang (56\%) memiliki persepsi 
keparahan negatif, sebagian besar yaitu 43 orang (52\%) memiliki persepsi manfaat negatif dan sebagian besar yaitu 44 orang (54\%) memiliki persepsi halangan yang negatif.

\section{Tabel 3}

Distribusi Frekuensi Pelaksanaan Tes HIV Ibu Hamil di Wialayah Kerja Puskesmas II Denpasar Barat Tahun 2018.

\begin{tabular}{llcc}
\hline No & $\begin{array}{c}\text { Pelaksanaan Tes } \\
\text { HIV }\end{array}$ & $\begin{array}{c}\text { Frek } \\
\text { (f) }\end{array}$ & $\begin{array}{c}\text { Persen } \\
(\boldsymbol{\%})\end{array}$ \\
\hline $\mathbf{1}$ & Belum & 22 & 27 \\
\hline $\mathbf{2}$ & Sudah & 60 & 73 \\
\hline & Total & 82 & 100 \\
\hline
\end{tabular}

Tabel 3 menunjukkan bahwa dari 82 responden, sebagian besar responden yaitu 60 orang $(73 \%)$ sudah melaksanakan tes HIV.

\section{Tabel 4}

Hubungan Persepsi Ibu Hamil tentang HIV/AIDS dengan Pelaksanaan Tes HIV di Wilayah Kerja Puskesmas II Denpasar Barat Tahun 2018.

\begin{tabular}{lllll}
\hline \multirow{2}{*}{ Persepsi } & \multicolumn{2}{c}{$\begin{array}{c}\text { Pelaksanaan } \\
\text { Tes HIV }\end{array}$} & Nilai \\
\cline { 2 - 4 } & & p \\
\cline { 2 - 4 } Kerentanan & & Belum & Sudah & \\
\cline { 2 - 4 } & Pegatif & $18(40)$ & $26(60)$ & 0,002 \\
\multirow{2}{*}{ Keparahan } & Positif & $4(11)$ & $34(89)$ & \\
\cline { 2 - 4 } & Negatif & $17(37)$ & $29(63)$ & 0,019 \\
\hline \multirow{2}{*}{ Manfaat } & Negitif & $5(14)$ & $31(86)$ & \\
\cline { 2 - 4 } & Positif & $17(40)$ & $26(60)$ & 0,006 \\
\hline Halangan & Negatif & $17(39)$ & $27(87)$ & \\
\cline { 2 - 4 } & Positif & $5(13)$ & $33(87)$ & 0,009 \\
\hline
\end{tabular}

Berdasarkan tabel 4, didapatkan data dari 38 orang yang memiliki persepsi kerentanan positif, hampir seluruhnya yaitu 34 orang (89\%) sudah melaksanakan tes HIV dengan nilai $\mathrm{p}=0,002$ yang berarti ada hubungan signifkan antara persepsi kerentanan yang positif tentang HIV/AIDS dengan pelaksanaan tes HIV. Ibu hamil yang memiliki persepsi kerentanan yang positif tentang HIV/AIDS akan meningkatkan kemauannya untuk melakukan tes HIV pada saat hamil. Hasil penelitian ini sejalan dengan penelitian Puri (2016) yang mengungkapkan bahwa ada pengaruh antara persepsi kerentanan dengan kelengkapan status imunisasi[6]. Hal ini juga sejalan dengan penelitian Wakhida (2016) yang mengungkapkan bahwa ada hubungan persepsi kerentanan dengan penggunaan VCT. Ibu hamil yang memiliki persepsi kerentanan yang positif tentang penyakit HIV/AIDS akan meningkatkan penggunaan VCT[7].
Retnaningsih (2013) menyatakan bahwa, apabila seseorang merasa dirinya rentan untuk penyakit-penyakit yang dianggap serius, ia akan melakukan suatu tindakan tertentu, dan tindakan tersebut akan bergantung pada manfaat yang dirasakan dalam mengambil tindakan tersebut[8]. Persepsi seseorang mempengaruhi orang tersebut untuk mengambil keputusan, antara lain persepsi kerentanan (Perceived Susceptibility) yang dipahami sebagai pemikiran bahwa, semakin besar risiko yang dirasakan, semakin besar kemungkinan seseorang terlibat dalam perilaku untuk suatu tindakan pencegahan terhadap suatu penyakit[9]. Menurut penelitian Mapuranga (2015) yang dilakukan di Afrika Selatan, persepsi kerentanan juga dipengaruhi oleh pengetahuan ibu tentang HIV/AIDS. Seorang ibu hamil yang awalnya tidak mengetahui informasi tentang HIV/AIDS tidak akan mempunyai kemauan untuk melakukan tes HIV, namun saat mereka sadar bahwa mereka juga rentan terkena HIV/AIDS maka akan timbul kesadaran untuk melakukan tes HIV[10]. Berdasarkan hasil penelitian ini implikasi yang dapat diterapkan yaitu dengan adanya persepsi kerentanan yang positif dari ibu hamil tentang HIV/AIDS, maka ibu hamil tersebut akan termotivasi untuk melakukan tes HIV sehingga ibu hamil tersebut dapat mengetahui keadaannya terkait HIV/AIDS.

Sejumlah 36 orang yang memiliki persepsi keparahan positif, hampir seluruhnya yaitu 31 orang $(86 \%)$ sudah melaksanakan tes HIV dengan nilai $\mathrm{p}=0,019$. Priyoto (2014) menyatakan bahwa, kepercayaan individu tentang keseriusan atau keparahan penyakit, sering didasarkan pada informasi medis, dari keyakinan seseorang bahwa ia akan mendapat kesulitan akibat penyakit dan akan berefek pada hidupnya secara umum[11]. Hasil penelitian ini sejalan dengan penelitian Wigati (2016) yang mengungkapkan bahwa ada pengaruh antara persepsi keparahan tentang kanker serviks dengan pelaksanaan tes HIV, dimana makin parah suatu penyakit maka seseorang akan melakukan upaya untuk melakukan pencegahan yaitu tes HIV[12]. Hasil penelitian lain yang sejalan adalah penelitian Ningrum (2016), yang mengungkapkan ada hubungan antara persepsi keparahan dengan penggunaan VCT[13].

Persepsi keseriusan sering didasarkan pada informasi medis, pengetahuan atau keyakinan seseorang bahwa dia akan mendapat kesulitan akibat penyakit yang akan mempersulit hidupnya[13]. Keparahan yang dirasakan menentukan ada tidaknya tindakan pencegahan 
yang dilakukan terhadap penyakit tersebut dalam hal ini penyakit HIV/AIDS, yang membuat individu bersedia untuk mencari informasi kemudian melakukan tes HIV untuk deteksi dini penyakit HIV/AIDS. Berdasarkan temuan dalam penelitian ini implikasi yang dapat diterapkan yaitu dengan adanya persepsi keparahan/keseriusan yang positif dari ibu hamil tentang HIV/AIDS, maka ibu hamil tersebut akan termotivasi untuk melakukan tes HIV.

Sejumlah 39 orang yang memiliki persepsi manfaat positif, hampir seluruhnya yaitu 34 orang (87\%) sudah melaksanakan tes HIV dengan nilai $\mathrm{p}$ $=0,006$. Priyoto (2014) menyatakan bahwa, seseorang cenderung mengadopsi perilaku sehat ketika percaya perilaku baru tersebut akan mengurangi risiko mereka untuk berkembangnya suatu penyakit. Semakin tinggi (positif) persepsi manfaat yang dirasakan, maka semakin besar keinginannya untuk melakukan tes HIV[9]. Hasil penelitian ini sejalan dengan penelitian Wakhida (2016) yang mengungkapkan bahwa ada pengaruh antara persepsi manfaat dengan penggunaan VCT[7].

Penelitian lain yang sejalan yaitu penelitian Ningrum (2016), yang mengungkapkan ada pengaruh antara persepsi manfaat dan kinerja kader pada pengendalian kasus tuberculosis[12]. Penelitian lainnya yaitu penelitian Wigati (2016), yang mengungkapkan bahwa ada pengaruh persepsi manfaat dengan pelaksanaan tes HIV[11]. Wanita yang semakin merasakan persepsi manfaat dari suatu tindakan untuk menghindari suatu penyakit, maka akan lebih memilih melakukan tindakan pencegahan penyakit tersebut. Berdasarkan hasil penelitian ini implikasi yang dapat diterapkan yaitu dengan adanya persepsi manfaat yang positif pada ibu hamil tentang pelaksanaan tes HIV, maka akan lebih meningkatkan kemauan ibu hamil untuk melakukan tes HIV. Hasil penelitian ini didukung oleh penelitian N.E. Bibiana (2018) di Nigeria, Persepsi manfaat sangat menentukan tindakan sesorang dalam melakukan tes HIV. Dari jumlah responden yang diteliti $90,1 \%$ percaya bahwa tes HIV sangat bermanfaat untuk ibu hamil untuk pencegahan penularan dari ibu ke anak, serta persiapan sebelum pernikahan[14].

Dari 38 orang yang memiliki persepsi halangan positif, hampir seluruhnya yaitu 33 orang $(87 \%)$ sudah melaksanakan tes HIV dengan nilai $\mathrm{p}$ $=0,009$. Hasil penelitian ini tidak sesuai dengan teori Health Belief Model dalam Ningrum (2016) yang mengatakan dalam melakukan tindakan pencegahan suatu penyakit maupun mencari pengobatan dipengaruhi oleh perceived barier yaitu hambatan yang timbul dalam melakukan suatu tindakan. Hambatan umum yang dialami seseorang dalam menentukan tindakan kesehatan atau memanfaatkan pelayanan kesehatan didominasi oleh kendala yang bersifat pribadi. Hambatan yang dirasakan merupakan unsur penentu terjadi perubahan perilaku atau tidak[12].

Penelitian lain adalah penelitian yang dilakukan Wigati (2016) tentang pengaruh persepsi hambatan dan pelaksanaan tes HIV dan penelitian Sutrisni (2016) yang mengungkapkan bahwa ada pengaruh antara persepsi hambatan dan kesediaan melakukan tes HIV[11][13]. Berdasarkan hasil penelitian ini, implikasi yang dapat diterapkan adalah dengan persepsi halangan yang negatif pada ibu hamil tentang pelaksanaan tes HIV, maka pelaksanaan tes HIV akan lebih mudah dilakukan pada ibu hamil.

Berdasarkan hasil analisis multivariat, variabel yang paling dominan berpengaruh terhadap pelaksanaan tes HIV adalah persepsi kerentanan dengan nilai $\mathrm{p}=0,004(95 \% \mathrm{CI}: 1,77-$ 19,49). Hal ini menunjukkan bahwa ibu hamil yang memiliki persepsi kerentanan positif yaitu ibu hamil yang mempunyai tanggapan positif mengenai risiko dirinya dan bayinya tertular HIV berpeluang 5,885 kali lebih besar untuk melaksanakan tes HIV dari pada ibu hamil yang memiliki persepsi kerentanan negatif.

\section{Simpulan}

Hasil penelitian yang telah dilaksanakan didapatkan simpulan: terdapat hubungan yang signifikan antara persepsi kerentanan, persepsi keparahan, persepsi manfaat dan persepsi halangan ibu hamil tentang HIV/AIDS dengan pelaksanaan tes HIV. Dari keempat variabel yang telah diteliti, persepsi kerentanan ibu hamil merupakan variabel yang paling dominan yang berhubungan dengan pelaksanaan tes HIV.

Terdapat hubungan yang signifikan antara persepsi ibu hamil tentang HIV/AIDS dengan pelaksanaan tes HIV dan persepsi kerentanan merupakan variabel yang paling dominan yang mempengaruhi pelaksanaan tes HIV. Dari hasil penelitian ini disarankan untuk meningkatkan promosi kesehatan terkait pelaksanaan tes HIV pada ibu hamil serta manfaatnya sehingga ibu hamil bersedia melaksanakan tes HIV. 


\section{Ucapan Terimakasih}

Dalam pelaksanaan penelitian ini, peneliti mengucapkan terima kasih kepada Kepala Puskesmas II Denpasar Barat, Bidan Koordinator KIA di Puskesmas II Denpasar Barat dan semua ibu hamil yang telah bersedia menjadi responden dalam penelitian ini.

\section{Daftar Pustaka}

[1] Kementrian Kesehatan RI, Pedoman Pelayanan Antenatal Terpadu; ed. kedua, Jakarta: Kemenkes RI, 2012

[2] Kementrian Kesehatan RI, Pedoman Pelaksanaan Pencegahan Penularan HIV dan Sifilis dari Ibu ke Anak Bagi Tenaga Kesehatan; Jakarta: KemenKes RI, 2015

[3] Dinas Kesehatan Kota Denpasar, Profil Kesehatan Kota Denpasar. Denpasar. 2016

[4] Sriwitati, JDM, Determinan yang Berhubungan dengan Pemanfaatan Pelayanan Tes HIV pada Ibu Hamil di BPM Wilayah Kerja Puskesmas II Denpasar Barat. Jurnal Bidang Kesehatan Vol 6, No 2.Universitas Respati Indonesia. 2014

[5] Khosidah Amik dan Sugi Purwanti, Persepsi Ibu Rumah Tangga Tentang Voluntary Councelling And Testing (VCT) Terhadap Prilaku Pencegahan HIV-AIDS. Volume 7.2014

[6] Puri YE, Pengaruh Persepsi Ibu Tentang Imunisasi Ditinjau dengan Health Belief Model terhadap Kelengkapan Status Imunisasi. Universitas Sebelas Maret Surakarta. 2016

[7] Wakhida SW, Health Belief Model Tentang Faktor-Faktor yang Mempengaruhi Penggunaan VCT Pada Ibu Hamil Di Puskesmas Kota Malang. Universitas Sebelas Maret Surakarta. 2016
[8] Retnaningsih Ekowati, Akses Layanan Kesehatan. Raja Grafindo Persada: Jakarta. 2013

[9] Priyoto, Teori Sikap Dan Perilaku Dalam Kesehatan, Nuha Medika: Yogyakarta. 2014

[10] Mapuranga, B et al. 2015. Women's perception on HIV/AIDS testing during pregnancy a case of Mopani District in Nkowankowa Tzaneen South Africa. Journal of Health, Medicine and Nursing. ISSN 24228419 Vol.19, 2015.

[11] Wigati PW, Analisis Jalur Dengan Health Belief Model Tentang Penggunaan Skrining Inspeksi Visual Asam Asetat Untuk Deteksi Dini Kanker Serviks Pada Wanita Usia Subur Di Kota Kediri. Tesis. Universitas Sebelas Maret, Surakarta. 2016

[12] Ningrum DNS, Path Analisis Hubungan Pendidikan dan Konstruk Health Belief Model dengan Kinerja Kader Pada Pengendalian Kasus Tuberkulosis Di Puskesmas Baki Kabupaten Sukoharjo. Universitas Sebelas Maret Surakarta. 2016

[13] Sutrisni, Health belief Model dan Analisis Jalur Tentang Faktor Yang Mempengaruhi Kesediaan Tes Human Immunodeficiency Virus Pada Ibu Hamil Di Kota Kediri. Universitas Sebelas Maret Surakarta. 2016

[14] N.E Bibiana et al .2018. Knowledge, attitude and factors affecting voluntary HIV counseling and testing services among women of reproductive age group in an Abuja Suburb community, Nigeria. Medical Journal of Zambia, Vol. 45 (1): 13 - 22 (2018) 